\title{
O GENERO NIDULARIUM LEM. (BROMELIACEAE) NO ESTADO DO PARANÁ
}

\author{
Rosângela Capuano Tardivo' \\ Armando Carlos Cervi ${ }^{1,2}$
}

Recebido em 13/06/96. Aceito 31/12/97

\begin{abstract}
RESUMO - (O gênero Nidularium Lem. (Bromeliaceae) no Estado do Paraná). Este trabalho é um estudo taxonômico das espécies do gênero Nidularium no Estado do Paraná. O gênero está representado por seis espécies, três variedades e uma forma: $N$. billbergioides (Schult. f.) L. B. Sm. f. billbergioides; $N$. campo-alegrense Lem.; $N$. exostigmum Tardivo; $N$. gracile Tardivo; $N$. innocentii Leme var. innocentii; $N$. innocentii var. paxianum $(\mathrm{Mez}) \mathrm{L}$. B. Sm.; N. innocentii Lem. var. wittmackianum (Harms) L. B. Sm. e N. procerum Lindman. São apresentadas chaves de identificação, descrições, ilustrações e distribuição geográfica dos táxons estudados
\end{abstract}

Palavras-chave: Nidularium, Bromeliaceae, taxonomia

\begin{abstract}
ABSCTRACT - (The genus Nidularium Lem. (Bromeliaceae) in Paraná State). This work is a taxonomic study of Nidularium species in Paraná State. The genus is represented by six species, three varieties and one form: $N$. billbergioides (Schult. f.) L. B. Sm. f. billbergioides; $N$. campo-alegrense Leme; $N$. exostigmum Tardivo; $N$. gracile Tardivo; $N$. innocentii Lem. var. innocentii, $N$. innocentii var. paxianum (Mez) L. B. Sm.; N.innocentii var. wittmackianum (Harms) L. B. Sm. e N. procerum Lindman. Identification keys, descriptions, illustrations and geographical distribuiton of the taxa studied are presented.
\end{abstract}

Key words: Nidularium, Bromeliaceae, taxonomy

\section{Introdução}

A família Bromeliaceae possui cerca de 2.800 espécies distribuídas em 50 gêneros, predominantemente neotropicais. Atualmente a familia encontra-se dividida em três subfamílias baseadas nos caracteres florais e na morfologia de frutos e sementes: Pitcairnoideae (Meisner) Harms, Tillandsioideae (Dumortier) Harms e Bromelioideae. No entanto, Brown \& Gilmartin (1989b) e Brown (1993) apud Leme \& Marigo (1993) em estudos ainda não concluídos, sugerem a criação de duas novas subfamílias: Cryptanthioideae e Navioideae.

\footnotetext{
Universidade Federal do Paraná, Departamento de Botânica, Centro Politécnico, Jardim das Américas, CEP 81531-970, Curitiba, PR

Bolsa de Pesquisa, CNPq
} 
O Brasil abriga cerca de $40 \%$ das espécies catalogadas, com vários gêneros endêmicos encontrados principalmente na Floresta Atlântica, ecossistema que abriga grande diversidade e quantidade de bromélias. Porém, ocorrem também nas restingas, nos campos rupestres, nos campos de altitude, na caatinga e em algumas regiões da Amazônia e do Pantanal do Mato Grosso (Leme \& Marigo 1993). Com a exploração constante de seu maior ecossistema, além do interesse de colecionadores e comerciantes, atraídos pelas inúmeras espécies ornamentais, as bromélias correm sério risco de desaparecimento e carecem de urgentes estudos e medidas de conservação.

O Paraná possui, ainda, a porção mais conservada de Floresta Atlântica do Brasil, com grandes áreas em forma de Parques e Reservas. Entretanto, pouco se conhece sobre a flora bromeliológica deste Estado. Este trabalho é uma contribuição ao estudo taxonômico, especificamente no território paranaense, do gênero Nidularium Lem. pertencente à subfamília Bromelioideae. Na última revisão desta subfamília, realizada por Smith \& Downs (1979), são citadas 23 espécies para a flora brasileira. Hoje são conhecidas cerca de 60 espécies, encontradas principalmente no Rio de Janeiro, sendo que algumas delas estão ameaçadas de extinção.

\section{Material e métodos}

Esta pesquisa foi baseada em material obtido em coletas realizadas no Estado do Paraná e de vários materiais-tipo e exsicatas provenientes dos seguintes herbários: B, GH, HB, HBR, LG, M, MBM, PKDC, RB, SP, UPCB e US.

A nomenclatura utilizada na descrição morfológica das espécies foi baseada em Mez (1891), Font Quer (1953), Smith \& Downs (1979), Stearn (1983), Brown \& Gilmartin (1984, 1989 a) e Pereira \& Leme (1986). Para a identificação das espécies utilizou-se os seguintes trabalhos: Mez (1891, 1896, 1934-1935), Smith \& Downs (1979), Reitz (1983), Pereira \& Leme (1986) e Leme (1994).

\section{Resultados e discussão}

Gênero Nidularium Lem., Jard. Fleur. 4 (Misc.): 60. 1854.

Planta terrestre, rupícola ou epífita, estolonífera ou não. Folhas 13-40, suberetas ou arqueadas, membranáceas ou coriáceas, formando roseta amplamente aberta ou infundibuliforme; bainha elíptica ou oval, coberta por escamas em ambas as faces, margem inteira; lâmina lanceolada, ligulada, sublinear ou linear, levemente ou distintamente estreitada em direção à base, canaliculada ou não, ápice agudo, obtuso, acuminado ou apiculado, margem geralmente serrilhada. Escapo floral ereto, geralmente muito curto ou mais longo que a roseta foliar, geralmente coberto por brácteas. Inflorescência composta, subcorimbosa ou capituliforme, formada por flores em fascículos, envolvida por brácteas estéreis, vistosas. Brácteas primárias ovadas, ovado-lanceoladas, estreitamente ovadas, ovado-triangulares ou estreitamente triangulares, ápice agudo, apiculado, acuminado ou caudado; verdes, róseas, vermelhas, purpúreas, amarelas ou alaranjadas, eretas, suberetas ou com porção terminal 
encurvada, geralmente escamosas, margem serreada ou espinulosa. Fascículos ou ramos com 2-11 flores, sésseis ou pedunculados, subflabelados, flabelados, obovados, pulvinados. Brácteas florais menores que as sépalas ou raramente de igual tamanho, ovadas, subtriangulares, triangulares ou lanceoladas, margem inteira, levemente crenada, serreada ou fortemente denteada em direção ao ápice, carenadas ou não, ápice agudo, apiculado, obtuso ou acuminado. Flores cleistógamas ou casmógamas, geralmente sésseis ou pediceladas. Sépalas concrescidas na base, simétricas ou assimétricas, lanceoladas, obovadas, elípticas ou oblongas, carenadas ou não, ápice acuminado, mucronado, apiculado ou obtuso. Pétalas concrescidas na base, formando um tubo, lâminas suberetas, eretas ou patentes, sem apêndices ou às vezes com calosidades na base da face interna, brancas, róseas ou azuis, ápice obtuso e cuculado, acuminado, agudo ou apiculado. Estames inclusos, filetes epipétalos. Anteras lineares, dorsifixas à metade de seu comprimento ou a um terço acima da base, ápice obtusoacuminado, mucronado ou agudo, base obtusa ou sagitada. Grão de pólen biporado. Estígma espiral-conduplicado, branco. Ovário ínfero, trilocular, glabro ou lanuginoso, obovado, subelíptico, estreitamente elíptico ou oblongo. Tubo epígino nulo ou geralmente presente. Placentação axial ou apical. Rudimentos seminais obtusos, elípticos ou obovados. Fruto baga, com sépalas persistentes.

Tipo: Nidularium fulgens Lem., Jard. Fleur. 4 (Misc.): 60. 1854.

Distribuição geográfica: Bahia, Espírito Santo, Minas Gerais, Rio de Janeiro, São Paulo, Paraná, Santa Catarina e Rio Grande do Sul.

O gênero Nidularium é endêmico do Brasil. Caracteriza-se, fundamentalmente, por não possuir apêndices petaláceos. De acordo com Brown \& Terry (1992), os apêndices estão presentes em 14 dos 27 gêneros da subfamília Bromelioideae e, em alguns casos, servem como o carácter diagnóstico para o reconhecimento genérico. Em várias espécies de Nidularium desenvolve-se apenas uma calosidade na base ou nos bordos das pétalas. Este importante carácter taxonômico (pétalas nuas) o distingue de dois táxons muito próximos, Canistrum E. Morren e Wittrockia Lindm., cujas espécies, ao contrário, apresentam apêndices. A ausência de apêndices porém, não delimita as espécies de Nidularium e Neoregelia L. B. Sm. Desta forma, a circunscrição genérica entre as espécies destes dois gêneros está baseada em outros caracteres. Nas espécies de Nidularium, as flores são sésseis ou curto pediceladas e sempre se reunem em fascículos distribuídos desde a parte periférica até a parte central da inflorescência, sendo que nesta, o número de flores em cada fascículo é reduzido. Já em Neoregelia, as flores são visivelmente pediceladas e estão reunidas somente na parte central (inflorescência simples), comum na maioria das espécies.

Todas as espécies estudadas são epifitas facultativas, exclusivas da Floresta Atlântica. Enquadram-se entre as denominadas "bromélias-tanque" porque possuem a bainha foliar amplamente desenvolvida, acumulando água, fragmentos orgânicos, além de numerosos organismos aquáticos. As escamas foliares apresentaram-se bastante homogêneas, caracterizadas por organização concêntrica, com pequeno grupo de células na parte central e células alongadas radiais. 
As recentes pesquisas sobre o gênero Nidularium realizadas por Pereira (1973), Pereira \& Leme $(1984,1985,1986)$ e Leme $(1987,1989,1990,1993,1994)$ têm contribuído no esclarecimento de várias questões taxonômicas, bem como na inclusão de várias espécies novas.

Pereira \& Leme (1986) efetuaram estudo sobre o subgênero Canistropsis Mez e verificaram algumas características divergentes entre as espécies analisadas. No entanto, os autores não julgaram necessária a criação de um novo subgênero para Nidularium e alteraram os caracteres diagnósticos do subgênero Canistropsis através de uma emenda em sua descrição original.

Subgênero Nidularium Mez in Martius, Fl. bras. 3 (3): 212.1891

Gemellaria Pinell ex Antoine, Phyto-Icon. 44. 1884; nomen baseado em N. innocentii Lem.

Aregelia sensu Mez in C. De Candolle, Monog. Phan. 9. 61. 1896, non Kuntze 1891 Nidularium subgênero Pseudonidularium Mez, Repert. Sp. Nov. 16:5.1919. (Tipo: N. loeseneri Mez).

Nidularium subgênero Orthonidularium Mez, Pflanzenreich. IV. 32: 55.1934 (Tipo: N. fulgens Lem.).

Planta em regra não estolonífera. Fascículos da inflorescência flabeliformes e bem achatados. Bráctea floral, sépalas e ovário, em regra não lanuginosos. Pétalas concrescidas em cerca de dois terços, ou mais, de seu comprimento, com lâminas eretas e ápice obtuso ou cuculado.

Tipo: Nidularium fulgens Lem., Jard. Fleur. 4 (Misc.): 60. 1854.

Subgênero Canistropsis Mez in Martius, Fl.bras.3(3): 214.1891 emend. Pereira et Leme.

Aregelia subgênero Canistropsis (Mez) Mez, Pflanzenreich IV. 32: 51. 1934.

Planta em regra conspicuamente estolonífera. Fascículos da inflorescência não manifestamente achatados, subflabeliformes ou até pulvinados. Bráctea floral, sépalas e ovário lanuginosos. Pétalas concrescidas até metade de seu comprimento, com lâminas suberetas ou patentes e ápice acuminado, agudo ou apiculado.

Tipo: Nidularium microps E. Morren ex Mez, in: Mart., Fl. bras. 3 (3): 218.1891.

Chave para as espécies do gênero Nidularium Lem. no Estado do Paraná.

1. Escapo floral ultrapassando distintamente as bainhas foliares

2. Lobo da corola branco, com ápice agudo ou apiculado ..... 1. N. billbergioides

2. Lobo da corola azul, com ápice obtuso e cuculado

3. Lâminas foliares lineares, distintamente estreitadas em direção à base; brácteas florais estreitamente triangulares, densa e conspicuamente serreadas em direção ao ápice

4. N. gracile

3. Lâminas foliares liguladas, levemente estreitadas em direção à base; brácteas florais oblongas, ovais, elipticas ou lanceoladas, inconspicuamente serreadas em direção ao ápice 6. N. procerum 
1. Escapo floral do mesmo comprimento ou mais curto que as bainhas foliares.

4. Brácteas primárias vermelho-escuras, apenas levemente amareladas em direção à base

2. N. campo-alegrense

4. Brácteas primárias verdes na base e róseo-escuras a avermelhadas no ápice.

5. Brácteas primárias ca. $7 \mathrm{~cm}$ de comprimento; fascículos com 2-4 flores; estigma ultrapassando distintamente o comprimento das pétalas na antese

3. N. exostigmum

5. Brácteas primárias $8-18 \mathrm{~cm}$ de comprimento; fascículos com 2-9 flores; estigma incluso

5. $N$. innocentii

1. Nidularium billbergioides (Schult. f.) L. B. Sm., f. billbergioides, Contr. Gray Herb. 95: 42. 1931

Fig. 1-7

Hohenbergia billbergioides Schultes f. in Roemer et Schultes, Syst. (2): 1253. 1830.

Tillandsia terminalis Vell., Fl. Flum. 137. 1829 (1825); Icon 3. pl. 143. 1831 (1827). non terminale Ule, 1898.

Hohenbergia terminalis (Vell.) Beer, Brom.: 73. 1856.

Tillandsia citrina Burchell ex Baker, Journ. Bot. London 17: 235. 1879

Canistrum purpureum E.Morren, Belg. Hortic. 33. 195. 1883; nomen nudum

Aechmea billbergioides (Schultes f.) Baker, Handb. Bromel.: 38. 1889.

Aechmea purpurea Baker, Handb. Bromel.: 69. 1889.

Nidularium parviflorum Lindman, Sv. Vet.-Akad. Handbl. 24(8): 17 pl.1, f. 8-18. 1891.

Nidularium citrinum Mez, Repert. Sp. Nov. 17: 113. 1921.

Nidularium billbergioides (Schultes filius) L.B.Smith var. citrinum (Burchell ex Baker) Reitz,

Sellowia 14: 106. 1962.

Planta ca. $30 \mathrm{~cm}$ alt., epífita, rupícola ou terrestre, estolonifera; estolho $5-18 \mathrm{~cm}$ compr., 0,5-1,0cm diâm.; folhas 18-20, liguladas, suberetas, rosuladas; bainha larga, elíptica ou obovada, $6-11 \mathrm{~cm}$ compr., $4-7 \mathrm{~cm}$ larg., em ambas as faces pálido-esverdeada e escamas conspícuas castanho-escuras; lâmina $20-28 \mathrm{~cm}$ compr., $1,5-3,5 \mathrm{~cm}$ larg., freqüentemente estriada e estreitada em direção à base, esverdeadas em ambas as faces ou tornando-se purpúreas com escamas inconspícuas, margem densamente serreada, dentes ca. 0,5-1,0 mm compr., totalmente verdes ou com o ápice avermelhado, distanciados entre si $2-7 \mathrm{~mm}$, ápice atenuado ou brevemente acuminado. Escapo ereto, $16-40 \mathrm{~cm}$ compr., $0,3-0,5 \mathrm{~cm}$ diâm., esverdeado ou amarelado, duas a três vezes mais alto que as bainhas foliares. Brácteas do escapo $2-3$, ca. $7,5 \mathrm{~cm}$ compr., as inferiores subfoliáceas, as superiores estreitamente lanceoladas, escamosas em ambas as faces, margem densamente serreada. Inflorescência elíptica a subglobosa, $6,5-10 \mathrm{~cm}$ compr., $2,7 \mathrm{~cm}$ diâm., com 7 ramos subsésseis, subflabelados. Ramos inferiores $2-3,2,0-2,5 \mathrm{~cm}$ compr., 1,5-2,0 cm larg., 3-7 flores, os superiores com apenas 2 flores. Brácteas primárias ovado-lanceoladas, $4-7 \mathrm{~cm}$ compr., superando 2 ou três vezes os ramos, suberetas ou porção terminal encurvada, amarelas, alaranjadas ou purpúreas, margem densamente serrulada, em ambas as faces com escamas castanho-escuras, lanuginosa em direção à base. Brácteas florais larga ou estreitamente ovais, triangulares, 1-2 cm compr., 0,8$1,5 \mathrm{~cm}$ larg., inteiras, carenadas, providas de escamas fimbriadas em ambas as faces e 

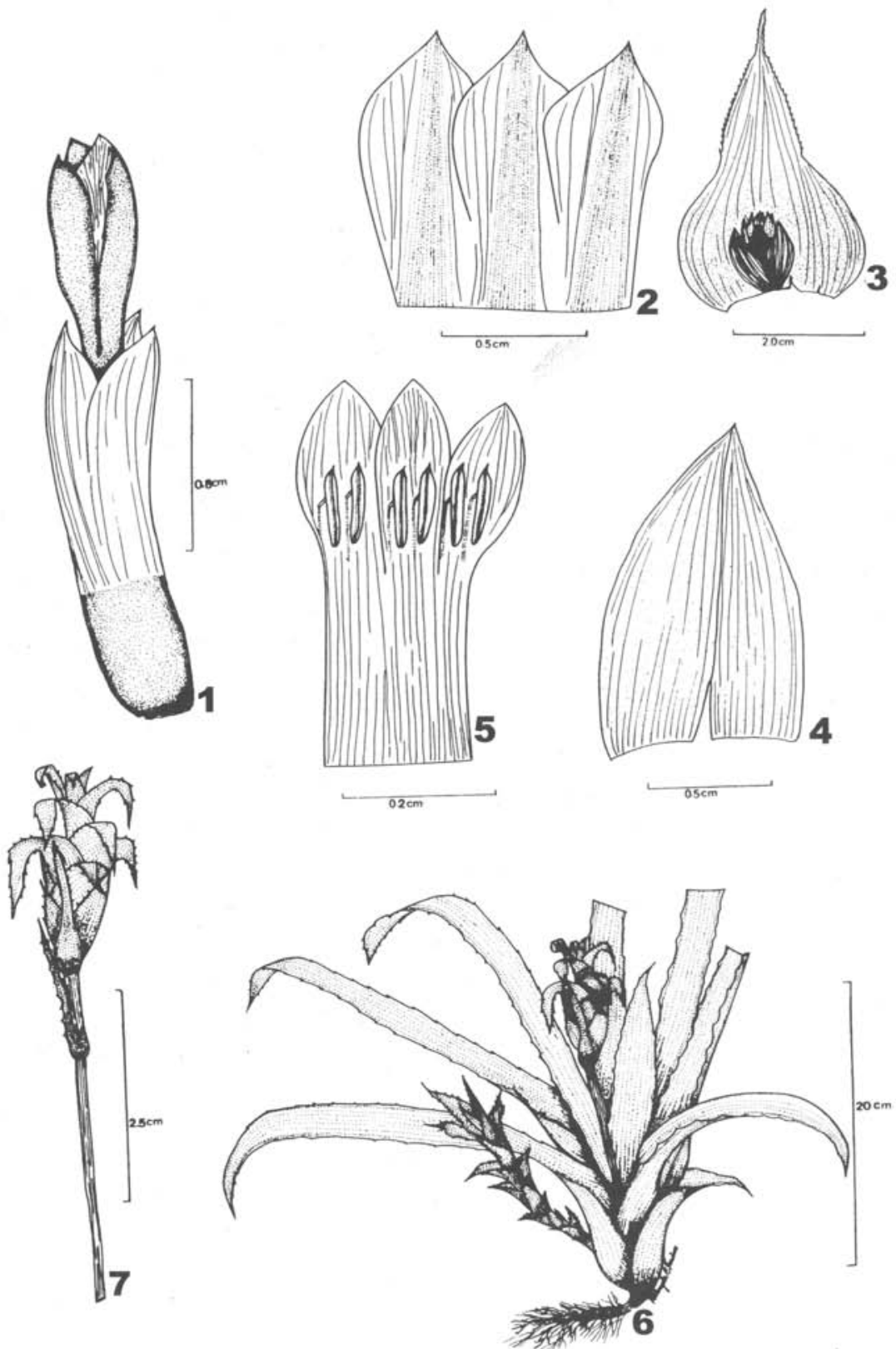

Figura 1-7. Nidularium billbergioides (Schult. f.) L. B. Sm. f. billbergioides. 1. Flor; 2. Sépalas; 3. Bráctea primária e ramo; 4. Bráctea floral - face dorsal; 5. Pétalas, mostrando o ápice agudo e estames; 6 . Hábito; 7. Inflorescência (3,6,7-planta cultivada; 1,2,4,5-Smith \& Reitz 5761). 
base com indumento lanoso, ápice agudo. Flores subsésseis, 2-2,8cm compr.; sépalas subsimétricas ou assimétricas, lanceoladas ou obovadas, apiculadas, obtusamente carenadas, $1,0-1,5 \mathrm{~cm}$ compr., conadas por $0,3-0,4 \mathrm{~cm}$ providas de escamas longamente fimbriadas, esverdeadas; pétalas $1,5-2,0 \mathrm{~cm}$ compr., conadas na base por $0,8-1,2 \mathrm{~cm}$, limbos na pré-antese subpatentes, alvos, ápice agudo ou arredondado e apiculado; estames inclusos na corola, filetes adnados sobre as pétalas; anteras $0,5 \mathrm{~cm}$ compr., lineares, base obtusa, ápice agudo, dorsifixas a um terço acima da base; ovário obovado, 0,6 cm compr., $0,65 \mathrm{~cm}$ diâm., trígono, alvo, glabro; tubo epígino ca. $0,1 \mathrm{~cm}$ compr.; placentação apical; rudimentos seminais geralmente elípticos.

Tipo: Bahia, Alamada, Ilhéus, Martius s.n. (holótipo M; foto US)

Distribuição geográfica: Bahia, Espírito Santo, Rio de Janeiro, São Paulo, Paraná e Santa Catarina.

Material examinado: BRASIL. Paraná: Guaratuba, 03/VIII/1969, Hatschbach 22090 (MBM). Santa Catarina: Florianópolis, Rio Tavares, 13/III/1952, Smith \& Reitz 6184 (US). Itapoá, Reserva Volta Velha.13/III/92, Negrelle A-145 (UPCB). São Paulo: Caraguatatuba-Ubatuba, Rio Escurto, 07/II/1968, Smith \& Mcwilliams 15420 (HB,US). Rio de Janeiro: Angra dos Reis, Mambucaba, Rio Pequerê, 25/ VIII/ 1976 Martinelli 1037 (HB). Espírito Santo: Guaraparí-Amarelos, 14/VIII/1975, Kautsky 505 (HB). Bahia: Ubaitaba, Rodovia Ubaitaba-Lages, $3 \mathrm{~km}$ Ubaitaba, 25/IV/1965, Belém \& Magalhães 947 (US).

Esta espécie inicialmente foi tratada como Tillandsia terminalis por Vellozo (1825). Smith (1931) propôs uma nova combinação a partir de Hohenbergia billbergioides Schult. f., resultando em N. billbergioides (Schult. f.) L.B.Sm. Segundo o autor, $N$. terminale seria uma homônimo posterior usado por Ule, em 1898.

Até a obra de Smith \& Downs (1979) N. billbergioides enquadrava-se no subgênero Nidularium. Pereira \& Leme (1986) transferiram-na para o subgênero Canistropsis Mez, devido ao ápice das pétalas agudo ou apiculado, entre outras características. No mesmo trabalho, os autores propuseram uma nova forma para a espécie, $N$. billbergioides f. azureum. Segundo eles, as populações da nova forma parecem estar concentradas somente entre Angra dos Reis e Paratí. Dentro do subgênero Canistropsis, $N$. billbergioides f. billbergioides é o táxon que apresenta a maior área de distribuição geográfica, ocorrendo desde o nordeste até o sul do Brasil.

$N$. billbergioides é uma espécie esciófila, típica do litoral brasileiro. Próxima do mar, possui hábito terrestre, onde convive $\operatorname{com} N$. innocentii Lem. e Canistrum lindenii E. Morren. No interior das florestas, até $600 \mathrm{~m}$ de altitude, ocorre como rupícola ou epífita. Geralmente forma agrupamentos de 2-10 indivíduos, raramente aparece isoladamente. Caracteriza-se por formar touceiras ascendentes devido ao rizoma estolonífero, pelo escapo bem desenvolvido e pelas pétalas brancas com ápice agudo ou apiculado.

O material examinado apresentou grande variação na coloração das brácteas primárias, que podem ser amarelas, alaranjadas ou purpúreas. Também foi constatada variabilidade na forma das sépalas em estudos realizados por Smith \& Downs (1979) e Pereira \& Leme (1986). 
Entre as espécies de Nidularium que ocorrem no Estado do Paraná, N. billbergioides é a única pertencente ao subgênero Canistropsis e pode ser considerada espécie rara, merecendo maiores buscas, principalmente no litoral.

2. Nidularium campo-alegrense Leme, Pabstia 5 (1): 12.1994 "campo-alegrensis". Fig. 8-15

Nidularium purpureum Beer var. albiflorum L. B. Sm. auct. non Beer: Reitz Fl. Il. Catarinense, Fasc. Brom.: 334. 1983.

Planta $27-34 \mathrm{~cm}$ alt., epífita ou rupícola. Folhas 13-20, arqueadas, rosuladas; bainha larga, oblongo-elíptica, 11,5-14cm compr., 7-8,2cm larg., em ambas as faces vinosas, com escamas inconspícuas castanho-ferrugíneas, margem inteira; lâmina $16-23 \mathrm{~cm}$ compr., $4,5-5 \mathrm{~cm}$ larg., sublinear, não canaliculada, em ambas as faces superficie estriada, verde, escamosa, margem levemente espinulosa, espinhos ca. $0,5 \mathrm{~mm}$ compr., purpúreos ou verdes, distanciados entre $5-13 \mathrm{~mm}$, ápice agudo ou acuminado, com porção terminal recurvada. Escapo 6,5-7,0cm compr., 8,5mm diâm., levemente recurvado, glabro, esbranquiçado. Brácteas do escapo 2 ou 3, a superior ca. $3 \mathrm{~cm}$ compr., as inferiores ca. $4,5 \mathrm{~cm}$, densamente escamosas, margem serreada, ápice acuminado. Inflorescência composta por 6-10 ramos, 10,5-12 cm compr., ca. $4,5 \mathrm{~cm}$ diâm. Brácteas primárias 9,5-11,5cm compr., ovado-lanceoladas, suberetas com a porção terminal recurvada, vermelho-escuras na parte superior e amareladas em direção à base, densamente escamosas, margem serreada. Ramos ca. $6,3 \mathrm{~cm}$ compr. e $1,4 \mathrm{~cm}$ larg., subflabelados, curto-pedunculados, com 2-3 flores. Brácteas florais 2,0-2,2cm compr., 1,5-1,6cm larg. largamente ovadas, membranáceas, carenadas, em ambos os lados densamente escamosas, ápice agudo ou subobtuso, apiculado, base lanada, margem inteira ou levemente crenada em direção ao ápice. Flores $5-7 \mathrm{~cm}$ compr., curto-pediceladas, pedicelo $0,3-0,4 \mathrm{~cm}$ compr.; sépalas levemente assimétricas, lanceoladas, esbranquiçadas, $2-2,5 \mathrm{~cm}$ compr., $0,6 \mathrm{~cm}$ larg., conadas por $5-7 \mathrm{~mm}$, ápice mucronado; pétalas ca. $4,7 \mathrm{~cm}$ compr., conadas na base por ca. $3,8 \mathrm{~cm}$, esbranquiçadas na base passando a verde-amareladas em direção ao ápice e totalmente alvas nos lacínios, ápice obtuso e cuculado; estames inclusos, filetes epipétalos; anteras ca. $5 \mathrm{~mm}$ compr., lineares, alvas, dorsifixas à metade de seu comprimento, base obtusa, ápice acuminado; ovário ca. $1,2 \mathrm{~cm}$ compr., $0,5-0,6 \mathrm{~cm}$ diâm., alvo, trígono, glabro, subelípitico; tubo epígino $0,1-0,2 \mathrm{~cm}$ compr.; placentação axial; óvulos elípticos.

Tipo: Santa Catarina, município de Campo Alegre, Morro do Iquererim (Quiri), 15.IV.1958, R.Reitz 5944 (holótipo HBR n.v.).

Distribuição geográfica: Paraná e Santa Catarina.

Material examinado: BRASIL, Paraná: Serra da Graciosa, 26/IV/1994, Tardivo 151 (UPCB); Quatro Barras, 26/IV/1994, Tardivo 152 (UPCB); Morro Sete, 26/IV/1994, Tardivo 153 (UPCB). Santa Catarina: Campo Alegre, 20/IV/1958, Reitz 5948 (HBR); Joinville, 20/IV/1958, Reitz 5946 (HBR).

Nidularium campo-alegrense é táxon recém-descrito para Santa Catarina, sendo esta sua primeira citação para a flora paranaense. Sua ocorrência é rara. Possui hábito 

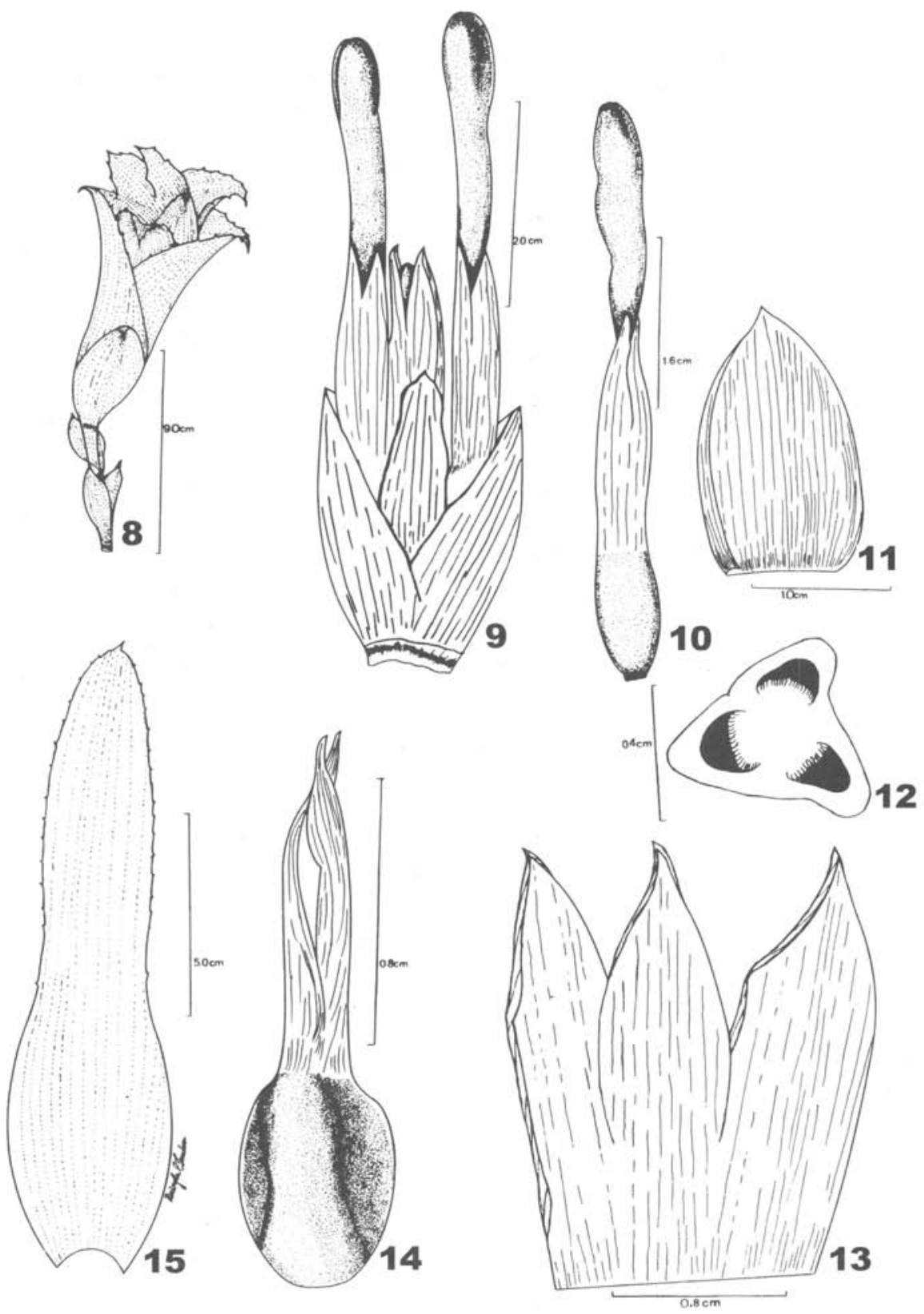

Figura 8-15-Nidularium campo-alegrense Leme.8-Inflorescência; 9-Ramo; 10-Flor, sem a bráctea floral; 11 Bráctea floral - face dorsal; 12-Corte transversal do ovário; 13-Sépalas; 14- fruto mostrando as sépalas persistentes; 15-Folha; (R.C.Tardivo 15I). 
rupícola ou epífita, ocupando sempre o estrato mais baixo das árvores, em locais muito úmidos e de pouca luminosidade. Geralmente, os indivíduos desenvolvem-se isoladamente, raramente observaram-se agrupamentos de 3 ou 4 indivíduos. Entre as espécies do gênero, $N$. campo-alegrense aproxima-se de $N$. innocentii Lem. devido à coloração alva nos lacínios das pétalas. Entretanto, diferencia-se desta por suas folhas não-canaliculadas, levemente espinulosas, ramos simples de, no máximo, 4 flores, sépalas estreitamente lanceoladas, com ápice agudo até acuminado, flores maiores com ca. $7 \mathrm{~cm}$ e brácteas florais pequenas, $2,0-2,2 \mathrm{~cm}$ comp. de margem inteira ou levemente crenada.

Difere das demais espécies pelas suas brácteas involucrais vermelho-carmim na parte superior e pela coloração purpúrea na bainha da folha. Floresce somente no mês de abril.

3. Nidularium exostigmum Tardivo, Bromélia, 2 (2): 26.1995.

Fig. 16-21

Planta 22-30cm alt., rupícola ou epífita. Folhas 14-16, liguladas, rosuladas; bainha 10-14cm compr., 5-5-8,0cm larg., oval, esverdeada, levemente alvacenta na base, margem inteira, densamente coberta por escamas castanho-pálidas em ambas as faces; lâmina 13-22cm compr., 4,2-6,0 cm larg., liguladas, canaliculadas, estreitadas em direção à base, margem serreada, espinhos ca. $0,5 \mathrm{~mm}$ compr., verdes, distanciados entre si por $4-7 \mathrm{~mm}$, esparsamente escamadas em ambas as faces, ápice agudo e apiculado. Escapo $4-7 \mathrm{~cm}$ compr., $0,7 \mathrm{~cm}$ diâm., esbranquiçado, glabro. Brácteas do escapo 2 a 3, ca. $3,5 \mathrm{~cm}$ compr., $1,6 \mathrm{~cm}$ larg., esverdeadas, margem serreada. Inflorescência $8-9 \mathrm{~cm}$ compr., ca. $3 \mathrm{~cm}$ diâm. Brácteas primárias 12, largamente ovadas, suberetas, as inferiores ca. $6,5 \mathrm{~cm}$ compr., as superiores $9,5 \mathrm{~cm}$ compr., esparsamente escamosas, verdes na base e róseo-avermelhadas em direção ao ápice, margem densamente serreada. Ramos ca. $5 \mathrm{~cm}$ compr., $1,8 \mathrm{~cm}$ larg., sésseis, flabelados, com 2 4 flores. Bráctea floral 2,0-2,2cm compr., ca.1,4cm larg., oblonga, margem inteira ou remotamente espinulosa no ápice, densamente coberta com escamas castanho-pálidas, ápice obtuso, levemente apiculado. Flor $4-5 \mathrm{~cm}$ compr.; sépalas ca. 1,8-2,3cm compr., $0,6-0,7 \mathrm{~cm}$ larg., conadas por $0,5-0,8 \mathrm{~cm}$, elíptico-obovadas, obtusamente carenadas, ápice agudo, apiculado; pétalas ca. $3,5 \mathrm{~cm}$ compr., conadas por $2,7 \mathrm{~cm}$, tubo esverdeado, lacínios alvos, oblongos, permanecendo eretos na antese, sem calos evidentes, ápice obtuso e cuculado; estames inclusos; anteras ca. $0,5 \mathrm{~cm}$ compr., amareladas, dorsifixas à metade de seu comprimento, base obtusa, ápice agudo; estígma excluso, ultrapassando o comprimento das pétalas por $1-2 \mathrm{~mm}$, bem visível na antese, estilete ca. $3,5 \mathrm{~cm}$ compr.; ovário trígono, glabro, alvo, $0,8 \mathrm{~cm}$ compr., $0,4-0,5 \mathrm{~cm}$ diâm.; placentação axial.

Tipo: BRASIL. Paraná: Rio São João, Estrada Velha Curitiba-Joinvile, próximo ao Km 76, 15/II/1994, Tardivo 141 (Holotipo UPCB).

Material adicional examinado: BRASIL. Paraná: Rio São João, Estrada Velha Curitiba-Joinvile, próximo ao Km 76, 28/V/1994, Tardivo 173 (MBM).

Esta espécie possui caracteres claramente diferenciados de suas congêneres. É semelhante à $N$. innocentii Lem., especialmente da variedade paxianum $(\mathrm{Mez}) \mathrm{L}$. B. 

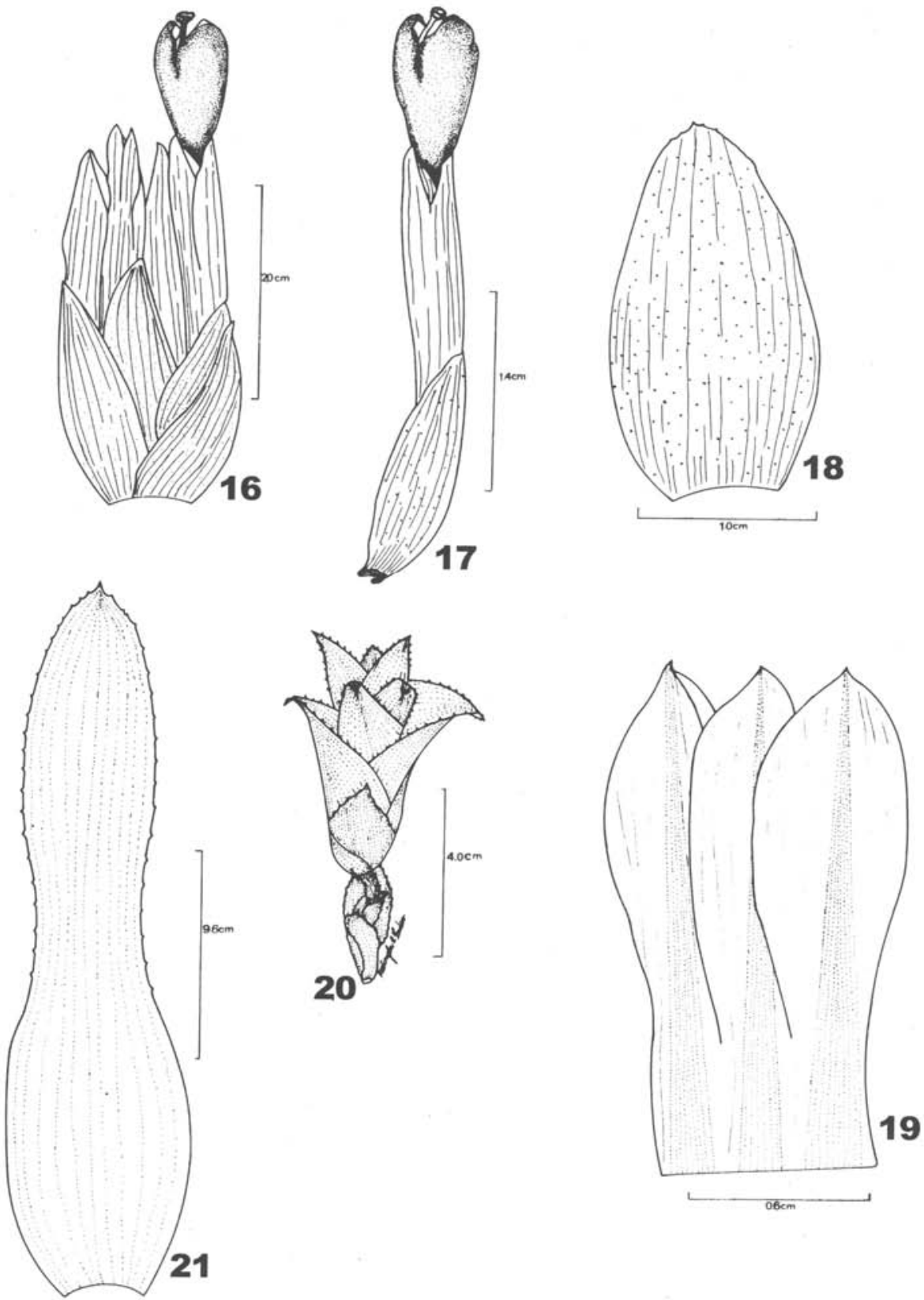

Figura 16-21-Nidularium exostigmum Tardivo. 16.Ramo; 17.Flor, com a bráctea floral, mostrando o estigma exserto; 18.Bráctea Floral - face dorsal; 19.Sépalas; 20.Inflorescência; 21.Folha. (R.C.Tardivo 141, holótipo). 
Sm. devido à coloração de suas brácteas primárias, verdes na base e róseas à avermelhadas no ápice. Porém, difere desta pelo seu tamanho reduzido, $22-30 \mathrm{~cm}$ altura, brácteas primárias menores, ca. $7 \mathrm{~cm}$ comp. e $5 \mathrm{~cm}$ larg. na base, ramos com 24 flores e pelo estigma exserto, ultrapassando distintamente o comprimento das pétalas na antese, característica esta, inédita para o gênero Nidularium.

As populações de $N$. exostigmum ocorrem juntamente com as de $N$. gracile, próximas à divisa do Estado de Santa Catarina. São plantas epífitas ou rupícolas, formando agrupamentos de 2-4 indivíduos. Florescem nos meses de fevereiro a maio.

4. Nidularium gracile Tardivo, Bromélia, 2(2): 29. 1995. Fig. 22-30

Planta ca. $45 \mathrm{~cm}$ alt., epifita, rupícola ou terrestre. Folhas 20-25, suberetas, rosuladas; bainha 7,5-12 cm compr., 2,8-5,5cm larg., elíptica, dotadas em ambas as faces de escamas castanho-escuras e manchas purpúreas irregularmente dispostas mais intensamente na face adaxial; lâmina ca. $85 \mathrm{~cm}$ compr., 1,8-3,0 $\mathrm{cm}$ larg., estreitatamente linear, distintamente estreitada em direção à base, verde, margens subdensamente serreadas, dentes $0,5-1 \mathrm{~mm}$ compr., distanciados ca. $4 \mathrm{~mm}$ entre si, tornando-se densamente serreada próximo ao ápice, escamas castanho-escuras esparsamente distribuídas em ambas as faces, ápice acuminado. Escapo ca. $15 \mathrm{~cm}$ compr., 5-7,5mm diâm., ereto, esbranquiçado, tornando-se esverdeado em direção à inflorescência, glabro. Brácteas do escapo 2, foliáceas, esbranquiçadas na base e verdes em direção ao ápice, margem densamente serreada. Inflorescência 9,0-9,5cm compr., obovada. Brácteas primárias oval-lanceoladas, $4-8,5 \mathrm{~cm}$ compr., ca. $3 \mathrm{~cm}$ larg. na base, suberetas ou com porção terminal recurvada, róseo-salmão no ápice e esverdeadas a esbranquiçadas em direção à base, escamosas em ambas as faces, margem serreada, dentes ca. $0,5 \mathrm{~mm}$ compr., acuminadas. Ramos 6, com 2-5 flores, subsésseis, flabeliformes, os inferiores $4,8 \mathrm{~cm}$ compr., $1-2 \mathrm{~cm}$ larg., os superiores $5 \mathrm{~cm}$ compr., $2,2 \mathrm{~cm}$ larg. Brácteas florais estreitamente triangulares, 2,1-3,0 cm compr., 0,6-1,0cm larg., carenadas, densa e conspicuamente serreada em direção ao ápice, em ambas as faces coberta com escamas castanho-pálidas; ápice agudo ou apiculado, com porção terminal recurvada. Flores subsésseis, $3,5-4,8 \mathrm{~cm}$ compr.; sépalas elípticas, simétricas, $1,4-2,0 \mathrm{~cm}$ compr., $1,5 \mathrm{~cm}$ larg., concrescidas na base por $0,5 \mathrm{~cm}$, esbranquiçadas, obtusamente carenadas, ápice subagudo; pétalas ca. $3 \mathrm{~cm}$ compr., conadas por $2-2,3,0 \mathrm{~cm}$, esbranquiçadas na base, lilás em direção ao ápice e totalmente azuis nos lacínios, ápice obtuso e cuculado, tenuamente calosa na base dos lacínios; estames inclusos, anteras $0,7-0,8 \mathrm{~cm}$ compr., lineares, dorsifixas à metade de seu comprimento, base obtusa, ápice mucronado; ovário trígono, glabro, azulado, ca. $0,8 \mathrm{~cm}$ compr., $0,5 \mathrm{~cm}$ diâm.; placentação axial, óvulos obovados.

Tipo: BRASIL. Paraná: Rio São João, Estrada Velha Curitiba-Joinvile, Km 76, 15/II/1994, Tardivo 140 (Holotipo UPCB; Isotipo MBM).

Material adicional examinado: Paraná: Rio São João, Estrada Velha Curitiba-Joinvile, nas proximidades do $\mathrm{Km}$ 76, 01/V/1994, Tardivo et al.167 (UPCB).

Esta espécie aproxima-se de $N$. antoineanum Wawra e $N$. procerum Lindm., pelo escapo ultrapassando distintamente as bainhas foliares e pelos lobos da corola 


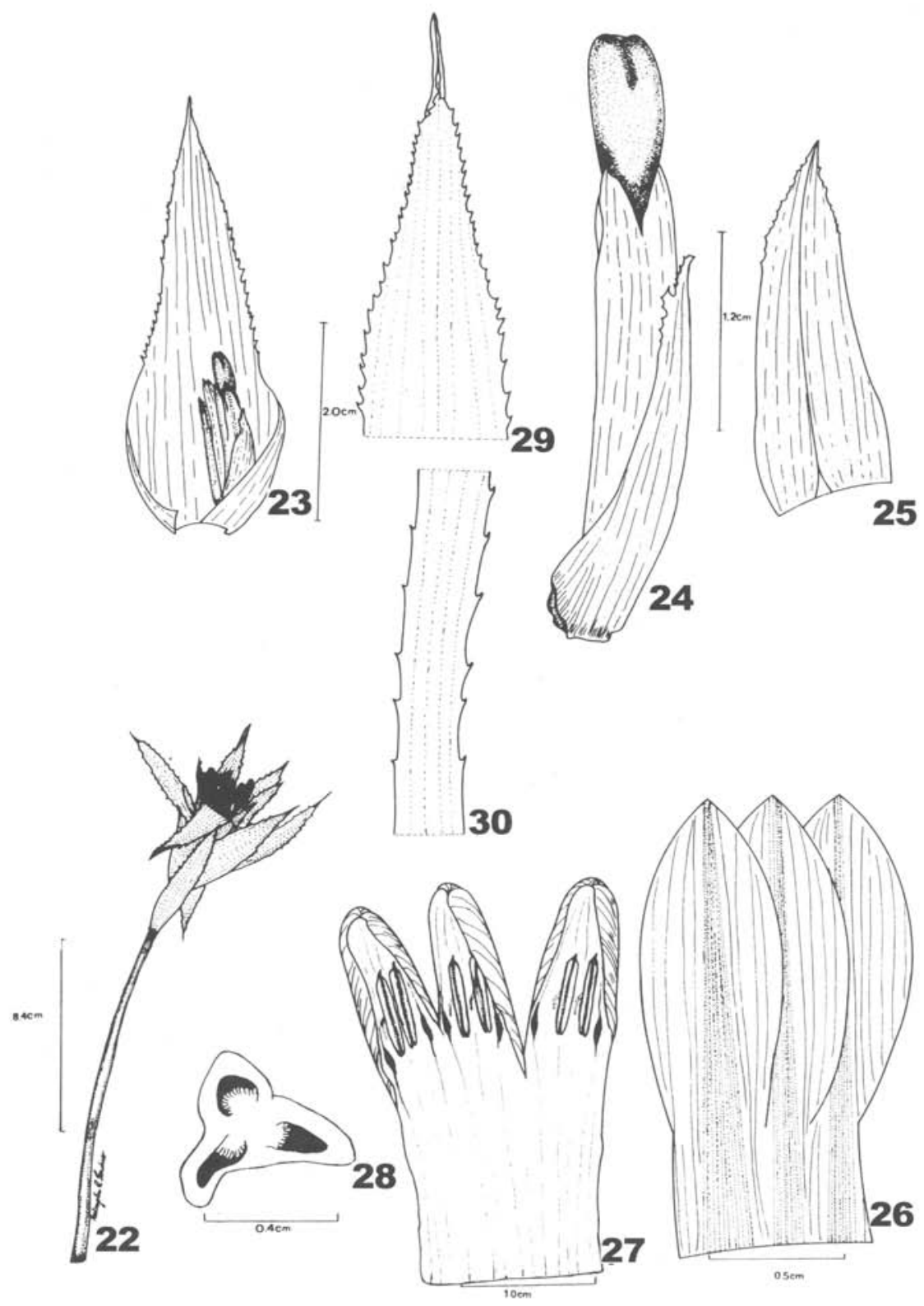

Figura 22-30- Nidularium gracile Tardivo. 22.Inflorescência; 23.Bráctea primária e ramo; 24.flor, com a bráctea floral; 25. Bráctea floral - face dorsal; 26.Sépalas; 27-Pétalas, mostrando a calosidade na base dos lacínios; 28.Corte transversal do ovário; 29 .Segmento apical da folha; 30 .Segmento da parte mediana da folha. (R.C.Tardivo 140, holótipo). 
azuis. No entanto, difere de ambas as espécies por suas folhas distintamente estreitadas em direção à base e pelas brácteas florais estreitamente triangulares, densa e conspicuamente serreadas em direção ao ápice, sendo os dentes irregularmente recurvados. Difere ainda de $N$. antoineanum pelo ápice foliar acuminado e de $N$. procerum pelas folhas com margem mediana subdensamente serreada, pela inflorescência delicada, não ultrapassando $10 \mathrm{~cm}$ diâm. na parte basal, com brácteas primárias de 7,0-8,5cm de comprimento e também pelas flores menores, com no máximo $4,8 \mathrm{~cm}$ compr.

As populacões desta espécie concentram-se próximas à divisa do Estado do Paraná com o Estado de Santa Catarina, a ca. 200m de altitude. São plantas terrestres, rupícolas ou epífitas, que preferencialmente formam agrupamentos de 3 até 11 indivíduos. Floresce nos meses de fevereiro até maio.

5. Nidularium innocentii Lem., Ill. Hortic. 2 (Misc.): 13. 1855. Fig. 31-39

Planta $30-60 \mathrm{~cm}$ alt., terrestre, rupícola ou epífita. Folhas 16-30, suberetas, rosuladas; bainha $8-14 \mathrm{~cm}$ compr., 7,5-9,0 $\mathrm{cm}$ larg., ovalada, esverdeada, levemente alvacenta na base, coberta densamente com escamas castanho-escuras em ambas as faces, margem inteira; lâminas $27-58 \mathrm{~cm}$ compr., $4,5-6 \mathrm{~cm}$ larg., liguladas, canaliculadas em direção à base, margem serreada, dentes 0,5 -lmm compr., castanho-avermelhados, distanciados entre si por 1-5mm; esparsamente escamosas em ambas as faces, ápice acuminado. Escapo 9-11 cm compr., 0,7-1,1 cm diâm., ereto, não ultrapassando as bainhas foliares, esbranquiçado, glabro. Brácteas do escapo 3-4, 4-7cm compr., esparsamente escamosas. Inflorescência ca. 9,5cm compr., $5,8 \mathrm{~cm}$ diâm., na parte mediana. Brácteas primárias 8 , ovado-lanceoladas, suberetas ou eretas apenas com a porção terminal recurvada; as inferiores ca. $8 \mathrm{~cm}$ compr., as superiores $14-18 \mathrm{~cm}$ compr.; margem levemente serreada em direção ao ápice, esparsamente cobertas com escamas castanhopálidas. Ramos 6-11, subsésseis, flabelados, os inferiores $3,7-5 \mathrm{~cm}$ compr., ca. $3,0 \mathrm{~cm}$ larg. com 4-9 flores; os superiores 3,0-3,5cm compr., 1,5-2 cm larg. com 2-3 flores. Bráctea floral 2,5 - 3,5cm compr., 1,8-2cm larg., ovalada, alvacenta, esparsamente escamosa, ápice agudo com margem inconspicuamente serreada. Flores ca. 6,5 $\mathrm{cm}$ compr.; sépalas $2,8-4,0 \mathrm{~cm}$ compr., conadas por $1,3-2,8 \mathrm{~cm}$, oblongas ou elípticas, simétricas ou levemente assimétricas, carenadas, alvacentas ou vermelhas, ápice agudo ou mucronado; pétalas ca. $5,2 \mathrm{~cm}$ compr., conadas por ca. $4,0 \mathrm{~cm}$, esbranquiçadas a esverdeadas na base e totalmente alvas nos lacínios, ápice obtuso e cuculado; estames inclusos, filetes epipétalos; anteras ca. $0,5 \mathrm{~cm}$ compr., lineares, amarelo-pálidas, dorsifixas à metade de seu comprimento, base obtusa, ápice agudo; ovário $1,0-1,5 \mathrm{~cm}$ compr., $0,5 \mathrm{~cm}$ diâm., trígono, alvo, glabro; placentação axial; tubo epígino ca. $0,3 \mathrm{~cm}$ compr.; óvulos elípticos.

Nidularium inocentii caracteriza-se pelo escapo curto, sépalas oblongas ou elípticas, brancas ou vermelhas, de ápice agudo ou levemente mucronado, brácteas florais ovaladas, inteiras ou insconspicuamente serreadas em direção ao ápice e lacínios das pétalas alvos. Possui grande variabilidade na coloração das folhas e brácteas primárias, o que proporcionou a criação de várias espécies novas, hoje enquadradas como variedades. 

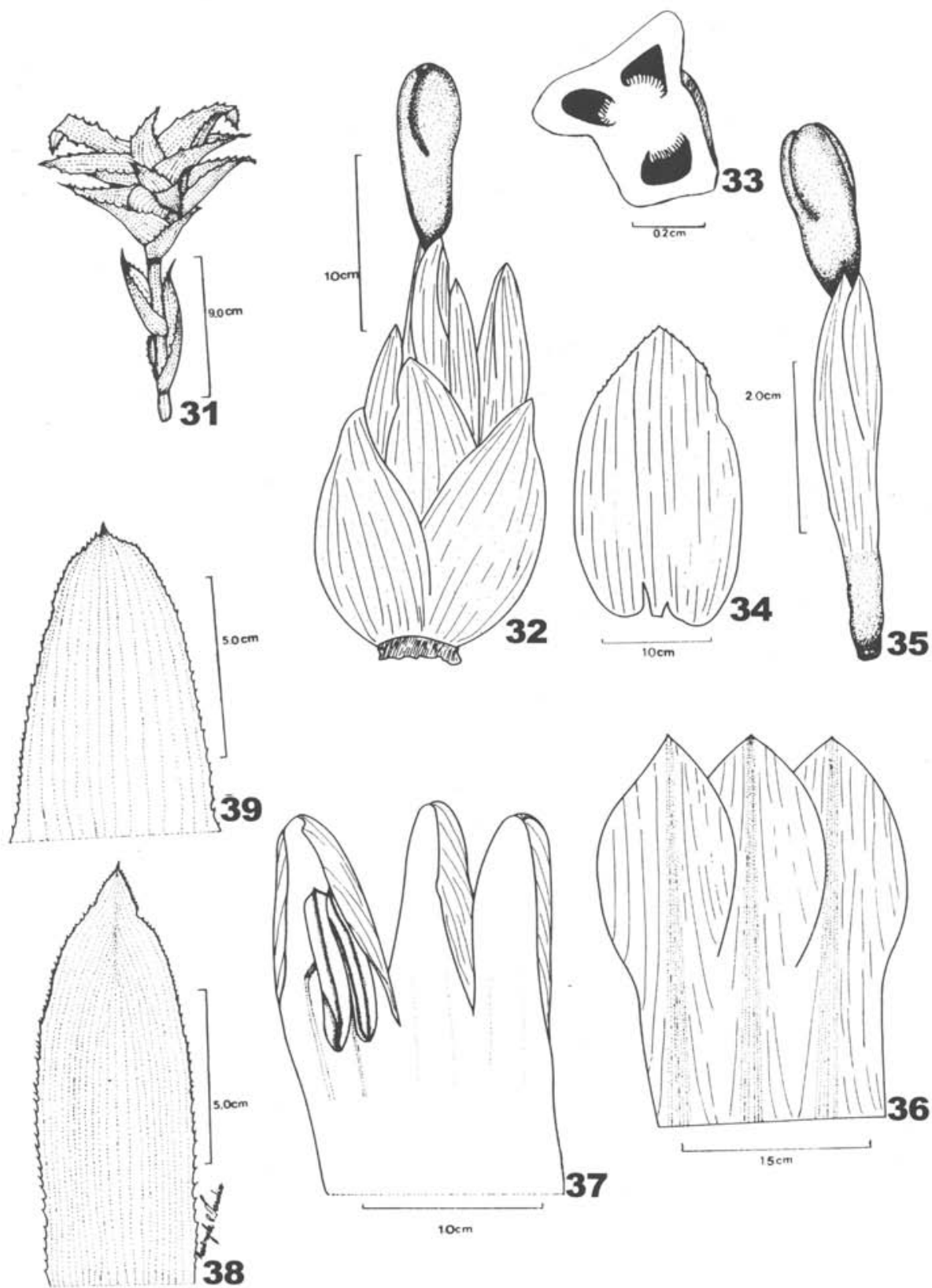

Figura 31-37; 34: Nidularium innocentii Lem. var. paxianum (Mez) L. B. Sm. 1-Inflorescência; 32.Ramo; 33.Corte transfersal do ovário; 34.Bráctea floral - face dorsal; 35.Flor, sem a bráctea floral; 36.Sépalas; 39.Pétalas; 9-Segmento apical da folha; (R.C.Tardivo 128). 38.N.innocentii var. wittmackianum (Harms) L. B. Sm. Segmento apical da folha. (R.Reitz 5739). 
Wittmack (1888) apud Smith \& Downs (1979, p.1614) enquadrou Nidularium striatum $\mathrm{B}$. Hortus como variedade de $N$. innocentii, caracterizada por lâminas foliares verdes com linhas longitudinais brancas. Esta variedade foi descrita através de material cultivado e tem sua provável distribuição no sul do Brasil.

Smith (1950) alterou $N$. paxianum Mez à variedade de $N$. innocentti. O autor diferenciou-a da variedade típica por suas folhas completamente verdes e o ápice das brácteas primárias, vermelho. Smith (1952) descreveu uma nova variedade, $N$. innocentii var. wittmackianum (Harms) L. B. Sm., caracterizando-a pelas suas folhas espinhosas e inteiramente vermelhas. Smith (1955) propôs uma nova combinação a partir de $N$. lineatum Mez, resultando em $N$. innocentii var. lineatum, cujo holótipo está depositado em Berlim e sua distribuição é conhecida apenas do material cultivado, proveniente do Brasil, sem local definido.

Pereira (1973) descreveu uma nova variedade para a espécie: $N$. innocentii var. bicolor, coletada por Alvin Seidel em fevereiro de 1973, no município de Castelo, Estado do Espírito Santo. Segundo o autor, a nova variedade difere da variedade típica e das outras variedades conhecidas por suas sépalas vermelhas e ápice das pétalas azulado.

A variedade mais recente foi descrita por Reitz (1981): N. innocentii var. bauense, caracterizada por linhas longitudinais amarelas sobre as lâminas foliares verdes e também sobre as brácteas florais; segundo o autor, a variedade possui aspecto bastante distinto das demais e é uma planta bastante rara, conhecida apenas pelo materialtipo, coletado no Morro do Baú, município de Ilhota, Santa Catarina.

O trabalho de Smith (1955) foi o primeiro a apresentar chave para a identificação das variedades de $N$. innocentii. Reitz (1983) citou quatro variedades para Santa Catarina: $N$. innocentii var. wittmackianum; $N$. innocentii var. paxianum; $N$. innocentii var. bauense e $N$. innocentii var. innocentii. Embora apenas três, das sete variedades de $N$. innocentii, ocorram no Paraná, observou-se que esta espécie é bastante freqüente, desde o nível do mar até $1.200 \mathrm{~m}$ de altitude.

Chave para as variedades de Nidularium inocentii Lem. ocorrentes no Paraná

1. Folhas com margens serreadas

2. Folhas inteiramente verdes; brácteas primárias verdes na base e róseas a vermelhas em direção ao ápice

5.2. var. paxianum

2. Folhas de coloração vinosa em ambas as faces ou somente na face abaxial; brácteas primárias inteiramente vermelhas ou com ápice verde

5.1. var. innocentii

1. Folhas com margens espinhosas

5.3. var. wittmackianum

5.1. Nidularium innocentii Lem. var. innocentii, Ill. Hortic. 2, Misc.: 13. 1855

Gemellaria innocentii Pinel ex Lem., Ill. Hort. 9: sub. Icon.3, 29.1862.

Karatas innocentii (Lem.) Antoine, Phyto-Icon.44, Icon.26, 1884.

Regelia innocentii Lem., Ill.Hort.7: sub.táb. 245, 1860.

Esta variedade possui $30-40 \mathrm{~cm}$ alt. Caracteriza-se pelas folhas de coloração vinosa em ambas as faces ou apenas na face abaxial, e brácteas primárias inteiramente vermelhas ou com o ápice verde. Planta esciófila, que se desenvolve em solo úmido, 
humoso ou em estratos mais baixos das árvores. Apesar da ampla distribuição geográfica, $N$. innocentii var. innocentii pode ser considerada rara, pois normalmente são encontrados pouquíssimos indivíduos habitando determinada área. Floresce no mês de abril.

Tipo: Lectótipo: Icon 3, in Ill. Hort. 9, 29. 1862.

Distribuição geográfica: Bahia, Espírito Santo, Rio de Janeiro, São Paulo, Paraná e Santa Catarina.

Material examinado: BRASIL. Paraná: Paranaguá, Rio das Pombas, 12/IV/1969, Hatschbach 21331 (MBM, US). Santa Catarina: Santo Amaro da Imperatríz, 06/IV/1956, Reitz et Klein 3018 (HBR). Rio de Janeiro: Madalena, mata da Rifa, 20/I/1957, Emygdio 1218 (US). Espírito Santo: Santa Maria Madalena, XI/1960, Seidel, s.n. (US).

5.2. Nidularium innocentii var. paxianum (Mez) L. B. Sm., Anais Bot. Herb. Barbosa Rodrigues 2: 14. 1950.

Nidularium paxianum Mez, Gartenflora 44: 297. 1895.

Planta $30-60 \mathrm{~cm}$ alt. Diferencia-se das outras variedades pelas folhas inteiramente verdes e brácteas primárias que variam de rosa, no início da floração, a vermelhas, no término da floração e início da frutificação. Epífita facultativa, pois se desenvolve também em solo úmido, em lugares sombreados da floresta.

Dentre as variedades encontradas no Paraná, $N$. innocentii var. paxianum é a mais freqüente e abundante. Ocorre desde litoral até $1.200 \mathrm{~m}$ de altitude. Ao contrário de $N$. innocenti var. innocentii esta variedade possui distribuição bastante uniforme em toda a área de ocorrência. Floresce de agosto a maio.

Tipo: Holótipo perdido. Tipo a nomear.

Distribuição geográfica: Minas Gerais, Espírito Santo, Rio de Janeiro, São Paulo, Paraná, Santa Catarina e Rio Grande do Sul.

Material examinado: BRASIL. Paraná: Curitiba, Ribeirão do Cedro, 12/XI/1961, Pabst 6743 et Pereira 6917 (HB). Estrada Guaratuba-Garuva, 15/II/1994, Tardivo et al. 143 (UPCB). Estrada Curitiba- Morretes, Serra do Mar, 29/VIII/1939, Kullmann 41568 (US, GH). Estrada Curitiba-Paranaguá, 15/IX/1953, Reitz 5738 (HBR); Guaraqueçaba, Rio Poruquara, APA de Guaraqueçaba, 08/I/1994 Pereira s.n (UPCB). Morretes, Serra do Mar, Porto de Cima, 06/I/1914, Dusén 14311 (US); Caminho dos Jesuitas, Parque Estadual Pico do Marumbi, 01/XI/1993, Tardivo et al. 128 (UPCB); Pontal do Sul, Balneário Barranco, 28/XI/1993, Tardivo et al. 129 (UPCB). Santa Catarina: Itajubá, 25/I/1988, Krapovickas et Cristobal 42120 (GH). São Francisco do Sul, Porto das Canoas, 21/II/1952, Smith et Reitz 5700 (US). SÃO PAULO: Serra do Mar, 10/VI/1951, Pires s.n (SP). Rio de Janeiro: Rio de Janeiro, Alto da Tijuca. 21/V/1974, Reitz 7608 (HBR). Minas Gerais: Osório, Lagoa dos Quadros, 28/I/1954, Rambo s.n.(HBR). 
5.3. Nidularium innocentii var. wittmackianum (Harms) L. B. Sm., Anais Bot. Herb. Barbosa Rodrigues 4: 34. 1952.

Nidularium wittmackianum Harms, Notizblatt 10: 220. 1928.

Planta $30-40 \mathrm{~cm}$ alt. Caracteriza-se pelas folhas espinhosas e aguçadas, avermelhadas ou totalmente vermelhas. As brácteas primárias são vermelhas no ápice e verde-amareladas em direção à base. Espécie esciófila, epífita ou rupícola.

No Paraná, assim como nos outros Estados em que ocorre, $N$. innocentii var. wittmackianum tem uma distribuição bastante restrita, ocorrendo em altitudes acima de $500 \mathrm{~m}$ e pode ser considerada rara. Floresce nos meses de agosto a maio.

Tipo: origem desconhecida, tipo obtido de cultivo no horto de Berlim (holótipo B, Isótipo B).

Distribuição geográfica: São Paulo, Paraná e Santa Catarina.

Material examinado: BRASIL. Paraná: Morretes, Estrada Curitiba-Paranaguá, Alto da Serra, 15/IX/1953, Reitz 5739 (B,US); Serra do Mar, Volta Grande, 16/IX/1915, Dusén 17206 (GH). Quatro Barras, 24/V/1987, Motta 804 (PKDC). Santa Catarina: Campo Alegre, Alpine Campo, Morro Iquererim, 08/XI/1956, Smith et Klein 7748 (HBR, US). São Paulo: Alto da Serra, 19/VIII/1939, Mulford et Foster 368 (GH).

6. Nidularium procerum Lindman, Sv., Vet-Akad, Handl. 24(8): 16, 189. Fig. 40-49

Aechmea purpurea Baker, Handb. Bromel. 69. 1889.

Canistrum purpureum E.Morren, Belg. Hortic. 33:195. 1883; nomen nudum

Nidularium porphyreum Mez, Mart. Fl.Bras. 3(3): 219. 1891.

Nidularium angustifolium Ule, Ner.Deutsch.Bot.Ges. 16: 351. 1898.

Nidularium affine Mez, Repert. Sp.Nov. Fedde 16: 4. 1919.

Karatas cardinalis Edinburg Hortus ex Mez, in Engler, Pflanzenreich IV.32: 61. 1934; nomen nudum.

Nidularium kermesianum Fritz Muller ex Ule, Ber.Deutsch.Bot.Gesellsch. 17: 359, 1898; nomen nudum.

Nidularium procerum Lindman var. kermesianum (Fr. Muller ex Ule) Reitz, Anais Bot. Herb. Barbosa Rodrigues 4: 18. 1952, syn. nov.

Planta 30-60 cm alt., epífita, terrestre ou rupícola. Folhas 18-40, suberetas, rosuladas, membranáceas ou subcoriáceas; bainha ca. $10-19 \mathrm{~cm}$ compr., $3,8-9 \mathrm{~cm}$ larg., elíptica ou ovalada, em ambas as faces totalmente verdes ou com manchas vinosas ou arroxeadas na base e nos bordos ou somente na parte mediana central, coberta densamente com escamas castanho-escuras; lâmina ligulada, $30-59 \mathrm{~cm}$ compr., ca. $2-5 \mathrm{~cm}$ larg., levemente estreitada em direção à base, verde, levemente ou completamente vinosa, não-canaliculada, esparsamente coberta por escamas castanho-ferrugíneas, ápice agudo e apiculado, apículo pungente, margem serreada, dentes ca. 0,5mm compr., distanciados entre sí de 2-6mm. Escapo ereto, 10-15,5cm compr., 0,6-0,9cm diâm., esbranquiçado, glabro. Brácteas escapais 2-3, foliáceas, $8-12 \mathrm{~cm}$ compr., densamente escamosas, margem serreada. Inflorescência 7,3-9cm compr., $4-5 \mathrm{~cm}$ diâm., na parte superior, obovada ou estrelada. Brácteas primárias 


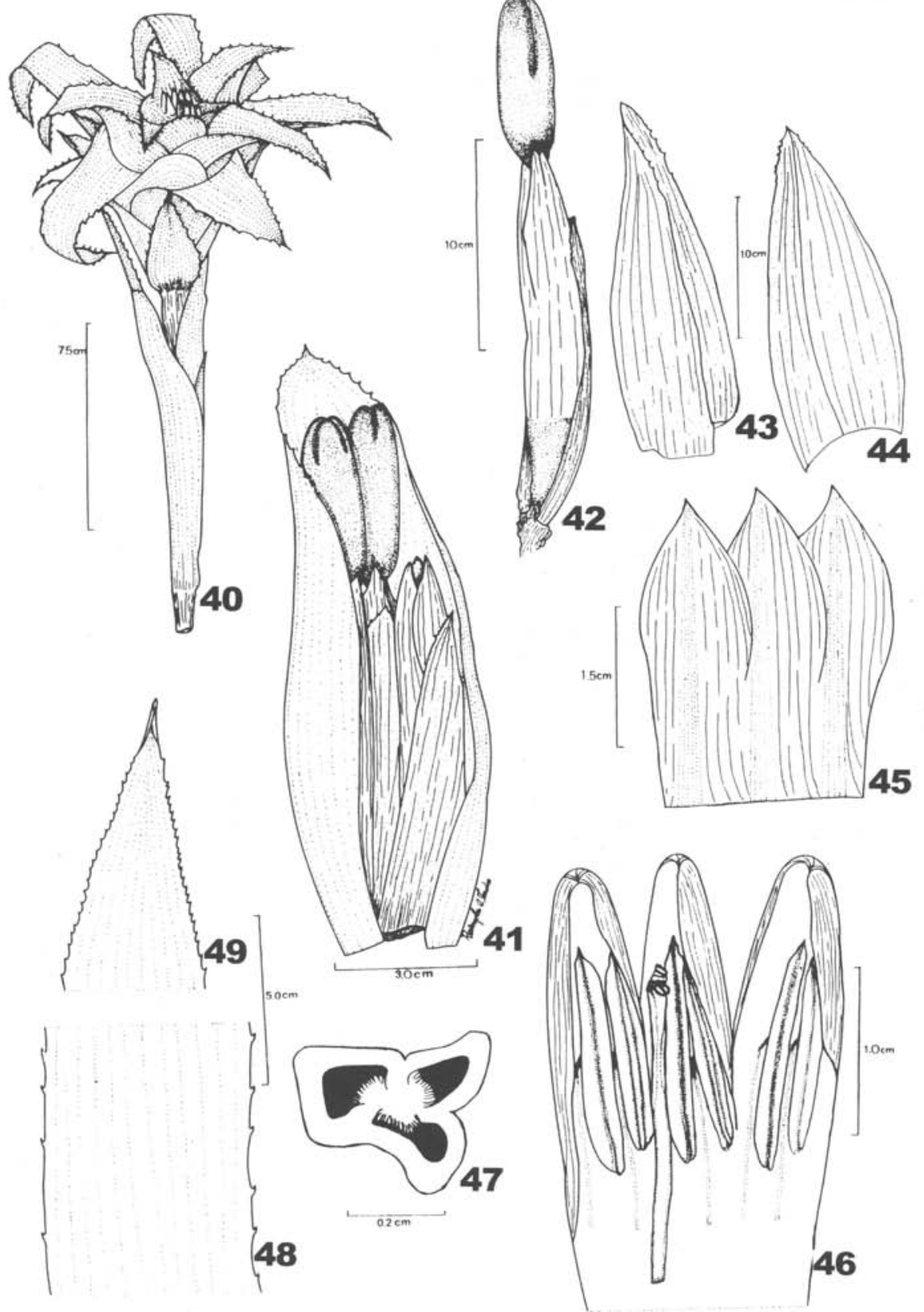

Figura 40-49- Nidularium procerum Lindman. 40. Inflorescência; 41.Bráctea primária e ramo; 42.Flor e Bráctea floral; 43. Bráctea floral-vista lateral; 44. Bráctea floral - face dorsal; 45.Sépalas; 46.Pétalas; 47.Corte transversal do ovário; 48.Segmento da parte mediana da folha; 49.Segmento apical da folha;(R.C.Tardivo 162). 
ca.16, as inferiores, 7-7,5cm compr., as superiores ca.12-14cm compr., ovado-lanceoladas, ápice agudo ou acuminado, esbranquiçadas a esverdeadas na base e vinosas em direção ao ápice, totalmente verdes ou avermelhadas em direção ao ápice ou completamente vinosas, margem serreada, dentes ca. $0,5 \mathrm{~mm}$ compr., verdes ou purpúreos. Ramos 6-7, ca.5,2-6cm compr., 2,2-3cm larg., com 3-6 flores, flabeliformes, curtamente pedunculados, pedúnculo ca. 0,3cm compr.. Brácteas florais 2,5-3,4cm compr., 1-1,2cm larg., oblonglas, ovais ou elipticas, com escamas castanho-pálidas esparsamente distribuidas, esbranquiçadas na base e verdes em direção ao ápice, geralmente carenadas, levemente serreadas em direção ao ápice agudo e apiculado, apículo recurvado, Flores 4,5-5,6 cm compr.; sésseis ou subsésseis, pedicelo $0,1-0,2 \mathrm{~cm}$ compr.; sépalas 2,0-2,5cm compr., concrescidas na base por $0,5-0,7 \mathrm{~cm}$, ca. $0,5 \mathrm{~cm}$ larg., lanceoladas, assimétricas, esbranquiçadas na base e verdes em direção ao ápice, fortemente carenadas, densamente escamadas na face interna, ápice agudo, geralmente apiculado; pétalas ca. $3,5 \mathrm{~cm}$ compr., concrescidas na base por $1-2,5 \mathrm{~cm}$, esbranquiçadas na base, tornando-se azuis nos lacínios, com bordos azulados, ápice obtuso e cuculado; estames inclusos; anteras ca. $0,9 \mathrm{~cm}$ compr., lineares, base obtusa, ápice mucronado, dorsifixas à metade de seu compr.; ovário $1,2-1,9 \mathrm{~cm}$ compr., $0,5 \mathrm{~cm}$ diâm., azulado, trígono, glabro; tubo epígino ca.0,4cm compr.; placentação axial; rudimentos seminais elípticos.

Tipo: São Paulo: Santos, 15/IV/1875, Mosén 3706 (holótipo S, n.v.; Isótipo US)

Distribuição geográfica: Santa Catarina, Paraná, São Paulo, Rio de Janeiro e Espírito Santo.

Material examinado: BRASIL. Paraná: Antonina, Mangue Maior Santo, 28/IV/1983, Hatschbach 46276 (MBM). Estrada Curitiba-Morretes, 29/VIII/1939, Kuhlmann 41571,(GH,US). Guaraqueçaba, Parque Nacional de Superaguí, APA de Guaraqueçaba, 19/V/1994, Tardivo et al. 171 (UPCB). Paranaguá, Sítio do Meio, 29/XII/1962, Hatschbach s.n. (MBM, UPCB). Quatro Barras, Morro 7, próximo ao Rio do Corvo. 26/IV/1994, Tardivo et al. 160 (UPCB). Santa Catarina: Florianópolis, Rio Tavares, 13/III/1952, Smith et Reitz 6186 (US). São Paulo: Santos, 15/IV/1875, Mosén 3706 (US). Rio de Janeiro: Angra dos Reis, Enseada do Leste, 29/VI/1977, Martinelli 2568 (US). Espírito Santo: Guarapari, Praia Setiba Pina, 21/IV/1975, Reitz 7825 (HBR).

Esta espécie, a princípio, foi tratada por Morren em 1883, como Canistrum purpureum. Baker (1889) tratou-a como Aechmea purpurea. Lindman (1891) a enquadrou no gênero Nidularium, e ressaltou as afinidades com N. ferdinando-coburgii Wawra, $N$. antoineanum Wawra, N. neglectum (Baker) M. Hortus ex Mez e N. scheremetiewii Regel, mas diferenciou-a destas principalmente pelo escapo floral muito elevado.

Müller (1898) apud Reitz (1952) descreveu-a como N. kermesianum, caracterizando-a por suas folhas totalmente vinosas. Reitz (1952) reduziu $N$. kermesianum a variedade de $N$. procerum Lindm. Esta variedade foi considerada em obras posteriores por Smith (1955), Smith \& Downs (1979) e Reitz (1983). De acordo com estes autores $N$. procerum var. kermesianum diferencia-se da variedade típica pelas folhas com até $40 \mathrm{~cm}$ comp. e não mais que $3 \mathrm{~cm}$ larg. e por apresentar porte menor, de no máximo $30 \mathrm{~cm}$ alt. 
No campo, foi possível observar que $N$. procerum é espécie polimórfica, pois assume aspecto diferente em resposta ao ambiente, especialmente quanto à coloração das folhas e brácteas involucrais. Não foram encontrados caracteres que justifiquem a manutenção de $N$. procerum var. kermesianum e, por esta razão, propõe-se a sua sinonímia.

As populações de $N$. procerum concentram-se especialmente no litoral, onde se desenvolvem isoladamente ou em agrupamentos de 2-10 indivíduos. Também são encontradas, mais esparsamente, até $1.200 \mathrm{~m}$ de altitude. $N$. procerum é planta esciófila que se desenvolve preferencialmente em lugares úmidos. Possui hábito terrestre, rupícola ou epífita, sendo que neste último, ocupa sempre o estrato mais baixo das árvores, ao lado de $N$. innocentti Lem. Caracteriza-se pelas sépalas lanceoladas, assimétricas, com ápice agudo e brácteas florais lanceoladas, levemente serreadas em direção ao ápice. Diferencia-se das demais espécies do subgênero Nidularium pelo escapo floral bem desenvolvido, com $10-15 \mathrm{~cm}$ alt., assemelhando-se, neste aspecto, a $N$. billbergioides e $N$. gracile. Floresce de janeiro a maio, porém é possível encontrar alguns exemplares floridos em agosto e setembro.

\section{Agradecimentos}

Os autores agradecem ao professor Dr. William A. Rodrigues por sua indispensável orientação, ao professor Olavo A. Guimarães pelas valiosas sugestões e ao pesquisador Elton M.C. Leme pela colaboração.

\section{Referências bibliográficas}

Baker, J. G. 1889. Handbook of the Bromeliaceae. London. George Bell Sons.

Brown, G. K. \& Gilmartin, A. J. 1984. Stigma structure and variation in Bromeliaceae - neglected taxonomic characteres. Brittonia 36(4): 364-374.

Brown, G. K. \& Gilmartin, A. J. 1989a. Stigma types in Bromeliaceae - A systematic survey. Systematic Botany 14(1): 110-132.

Brown, G. K. \& Gilmartin, A. J. 1989b. Chromosome numbers in Bromeliaceae. American Journal Botany 76(5): 657-665.

Brown, G. K. \& Terry, R. G. 1992. Petal appendages in Bromeliaceae. American Journal Botany 79(9): 1051-1071.

Font Quer, P. 1953. Dicionário de Botánica. Barcelona. Labor.

Leme, E. M. C. 1987. Novas Bromeliáceas nativas do Brasil-iv. Bradea 4(39): 309-326.

Leme, E. M. C. 1989. Novas Bromeliáceas nativas do Brasil-vi. Bradea 5(16): 166-187.

Leme, E. M. C. 1990. Novas Bromeliáceas nativas do Brasil-vii. Bradea 5(29): 319-324.

Leme, E. M. C. 1993. Novas Bromeliáceas nativas do Brasil-ix. Pabstia 4(1): 1-12.

Leme, E. M. C. 1994. Novas Bromeliáceas nativas do Brasil- xii. Pabstia 5(1): 12-15.

Leme, E. M. C. \& Marigo, L. C. 1993. Bromélias na natureza. Marigo Comunicação Visual Ltda.

Lindman, C. A. M. 1891. Bromeliaceae Herbarii Regnelliani.I-Bromelieae. Kongl. Svenka VetenskapsAkademiens Handligar 24(8): 19-24.

Mez, C. 1891. Bromeliaceae. In: Martius, C. F. P. Flora Brasiliensis. Weinheim. J.Cramer, 3 (3): $173-634$.

Mez, C. 1896. Bromeliaceae. In: C. De Candolle. Monographiae Phanerogamarum. Paris. Sumptibus Masson, $9(61)$ p. 1-144.

Mez, C. 1934-35. Bromeliaceae. In: A Engler, Das Pflanzenreich. Stuttgart. 4 (32): 38-70.

Pereira, E. 1973. Species novae in Brasilia Bromeliacearum-v. Bradea 1 (29): 313-319.

Pereira, E. \& Leme, E. M. C. 1984. Species novae in Brasilia Bromeliacearum- xxiv. Bradea 4 (11): 69-73.

Pereira, E. \& Leme, E. M. C. 1985. Species novae in Brasilia Bromeliacearum-xxvii. Bradea 4 (22): $149-156$.

Pereira, E. \& Leme, E. M. C. 1986. Contribuição ao estudo do gênero Nidularium (Bromeliaceae) - Parte 1subgênero Canistropsis. Bradea 4 (32): 219-254. 
Reitz, R. 1952. Species, Varietates, Combinationes novae et Criticae Bromeliacearum catharinensium. Anais Botânicos do Herbário Barbosa Rodrigues 4: 7-36.

Reitz, R. 1981. De variationibus in bromeliaceis. Sellowia 33:55-56.

Reitz, R. 1983. Bromeliáceas e a Malária - Bromélia endêmica. Flora Ilustrada Catarinense, 1-608.

Smith, L. B. 1931. Studies in the Bromeliaceae - II. Contributions Gray Herbarium Harvard University 95 (42): 40-49.

Smith, L. B. 1950. Notas sobre Bromeliáceas de Santa Catarina. Anais Botânicos do Herbário Barbosa Rodrigues 2: 13-15.

Smith, L.B. 1952. Bromeliáceas novas ou interessantes do Brasil-V. Arquivos de Botânica do Estado de São Paulo 2:195-198.

Smith, L. B. 1955. The Bromeliaceae of Brazil. Smithsonian Miscellaneous Collections 126 (1): 1-290.

Smith, L. B. \& Downs, R. J. 1979. Bromelioideae (Bromeliaceae). Flora Neotropica Monograph 14 (3):16041724.

Stearn, W. T. 1983. Botanical Latin. 3ed. Devon. David \& Charles.

Vellozo, J. M. C. 1825. Flora Fluminensis. Texto. Ed. Dommus Frater Antonio de Arrabida. Rio de Janeiro. 